\title{
COVID-19: COMPARISON OF SITUATIONAL FACTORS BETWEEN HEALTHCARE WORKERS AND NON-HEALTHCARE WORKERS IN EAST MALAYSIA
}

\author{
Phee Kheng Cheah ${ }^{1,2}$, Phaik Kin Cheah ${ }^{3}$, Darlene Ongkili ${ }^{4}$, Anne Osterrieder ${ }^{5,6}$, Tassawan Poomchaichote $^{5,7}$, \\ Naomi Waithira ${ }^{5,6}$, Mavuto Mukaka ${ }^{5,6}$ and Phaik Yeong Cheah' ${ }^{5,6,7}$. \\ ${ }^{1}$ Emergency and Trauma Department, Sabah Women \& Children's Hospital, Ministry of Health Malaysia, Sabah, Malaysia. \\ ${ }^{2}$ Emergency Department, Loh Guan Lye Specialist Centre, Penang, Malaysia. \\ ${ }^{3}$ Department of Public Relations, Universiti Tunku Abdul Rahman, Kampar, Malaysia. \\ ${ }^{4}$ Queen Elizabeth Hospital, Ministry of Health Malaysia, Sabah, Malaysia. \\ ${ }^{5}$ Mahidol Oxford Tropical Medicine Research Unit, Faculty of Tropical Medicine, Mahidol University, Bangkok, Thailand. \\ ${ }^{6}$ Centre for Tropical Medicine \& Global Health, Nuffield Department of Medicine, University of Oxford, Oxford, UK \\ ${ }^{7}$ The SoNAR-Global Network, Mahidol University, Bangkok, Thailand.
}

Corresponding author: Phee Kheng Cheah

Email: dr.cpkheng@gmail.com

\begin{abstract}
COVID-19 is one of the worst global pandemics in the last 20 years caused by Severe Acute Respiratory Syndrome Coronavirus 2. To control the pandemic in Malaysia, on $18^{\text {th }}$ March 2020 the government implemented the Movement Control Order (MCO), a non-pharmaceutical intervention (NPI) under Malaysia's Prevention and Control of Infectious Diseases Act 1988. Despite a high rate of compliance to the MCO in East Malaysia, a month after its implementation, a new cluster of infections among hospital healthcare workers (HCW) had emerged. This paper reports the early findings of a multinational study involving Malaysia, Thailand, Italy, and the United Kingdom. Our early analysis seeks to understand two main situational factors in the states of Sabah and Sarawak in East Malaysia - testing rates and household composition between HCW and non-healthcare workers (non-HCW). Our results showed that there were higher testing rates and smaller-sized households among HCW when compared to non-HCW workers.
\end{abstract}

Keywords: COVID-19, SARS-CoV-2, health care worker, household, non-pharmaceutical interventions, quarantine, isolation, screening, testing, Sabah, Sarawak, East Malaysia

\section{INTRODUCTION}

Coronavirus Disease 2019 (COVID-19) is the largest Coronavirus outbreak in the last 20 years ${ }^{1}$. As of $5^{\text {th }}$ June 2020, there were over 6.5 million infections and almost 390,000 deaths due to COVID-192. In Malaysia, there was a gradual increase in the number of cases after the first case was detected on $25^{\text {th }}$ January 2020 that was linked to a religious gathering in Sri Petaling, Kuala Lumpur Federal Territory. Following this, there was an exponential surge from 29 cases on $1^{\text {st }}$ March 2020 to 673 cases on $17^{\text {th }}$ March $2020^{3}$. In response to the rise in COVID-19 cases, the Malaysian government imposed the Movement Control Order (MCO) under the Malaysia's Prevention and Control of Infectious Diseases Act 1988 on $18^{\text {th }}$ March 2020. The MCO, a non-pharmaceutical intervention (NPI), prohibits inter-state movement, mass gatherings, and overseas travel for Malaysians; restricts entry for foreigners; and requires closure of all educational institutions and non-essential services ${ }^{4}$. East Malaysian states of Sabah and Sarawak have special provisions in the Malaysian law for control over immigration and are empowered to refuse entry to citizens who are not born in those states ${ }^{5}$. Before the national MCO, both states had enforced travel restrictions. They banned foreigners from or with travel history to mainland China and implemented compulsory 14-day home quarantine for state citizens returning from China ${ }^{6,7}$.

NPIs are effective methods to prevent and control infection while vaccines and other preventive treatments are being developed ${ }^{8}$. Contact tracing and early detection of cases, medical resource management and enhanced public health education are crucial in addition to NPIs to eliminate the disease ${ }^{1}$. Before the MCO, Malaysia had concentrated on testing symptomatic individuals with epidemiology link and faced challenges from inadequate testing facilities and reagents.

High MCO compliance rates were observed among the general public in Sabah and Sarawak, on the island of Borneo, East Malaysia at $96.8 \%$ and $97.3 \%$ respectively ${ }^{9,10}$. Despite that, clusters of COVID-19 cases related to healthcare workers ( $\mathrm{HCW}$ ) have been reported in several government hospitals in Sabah and Sarawak, whereby $70 \%$ of the cases were related to the HCW's social activities or travel history ${ }^{11,12}$. Whilst the conventional NPIs would work 
on the public, it is possible that a different approach is needed to address disease transmission between HCW.

This short report aims to investigate two situational factors - testing rates and household compositions between HCW and non-healthcare workers (nonHCW) in Sabah and Sarawak. This study is a part of an ongoing multinational study involving Malaysia, Thailand, Italy, and the United Kingdom ${ }^{13}$.

\section{METHODS}

Data collection commenced on $1^{\text {st }}$ May 2020 via a self-administered online survey. Ethical approval for this study was obtained from the Medical Research and Ethics Committee (NMRR-20-59554437 IIR), Ministry of Health Malaysia. Adults residing in Malaysia were recruited via email, social media, and recruitment posters. The data was analysed using Stata 15.0 software. Fisher's exact tests were used to assess associations between categorical variables, and Z-test for trend to test associations between binary and ordinal categorical variables with a $5 \%$ significance level.

\section{RESULTS}

The demographic characteristics of the 262 respondents in Sabah and Sarawak who completed the online survey between $1^{\text {st }}$ and $31^{\text {st }}$ May are shown in Table 1. The key variables were balanced between the states.

Table 2 illustrates that overall, in terms of testing, a higher percentage of $\mathrm{HCW}$ have been tested for COVID-19 (44\%) compared to the non-HCW group that reported only $5 \%$ in Sabah and Sarawak combined. The difference was statistically significant $(p<0.001)$. This trend was also true in both states. A higher proportion of HCW $(66 \%)$ in Sarawak reported they have been tested compared to HCW in Sabah $(26 \%)(p<0.001)$. There were no significant differences in the reported testing rates between Sarawak and Sabah for non-HCW.

Table 3 shows that overall, there was a significant difference in household composition between HCW and non-HCW, with $\mathrm{HCW}$ reporting $26 \%$ as being either single or living with spouse alone compared to $11 \%$ in the general population $(p=0.013)$. Overall, there was a difference in the number of people in a household between HCW and non-HCW $(p=0.009)$, with $\mathrm{HCW}$ reporting about $41 \%$ as having three or fewer people in the household compared to about $29 \%$ in the general population.

\section{DISCUSSION}

The results shed some light on two important themes. First is regarding testing for COVID-19. Our data showed that more HCW were tested compared to non-HCW or the public in both states, and more HCW in Sarawak were tested compared to Sabah. $\mathrm{HCW}$ are regarded as having a higher risk to contract COVID-19, and thus protocols are in place for testing $\mathrm{HCW}$. The higher number of HCW tested in Sarawak could be attributed to the mass screening in Sarawak General Hospital on $6^{\text {th }}$ May, $2020^{14}$. About $1 \% \mathrm{HCW}$ with no exposure to COVID-19 patients were reported to have contracted COVID-19 in the Netherlands and China in the beginning of the year $2020^{15}$. Another concern is that the public has not been widely tested. With cases of asymptomatic infection, low testing rates among the public may raise the numbers and burden the health care system. Wide testing was extensively employed by South Korea and Taiwan coupled with contact tracing to identify and isolate infected individuals early have proven to be effective ${ }^{16}$.

Secondly, the data showed that HCW in Sabah tend to live alone or have small-sized households. This could be because $\mathrm{HCW}$ realised they may potentially be infected, and voluntarily quarantined or distanced themselves from family members. The Malaysian public have been found to be concerned about transmitting the disease to others, and having their loved ones getting infected with COVID-19 ${ }^{17}$.

The limitation of this study is that it only captured data from smart phone or computer users with internet access. It did not include people that are computer-illiterate or without good internet connection, such as those living in the rural areas of Borneo or lower income population. Face-to-face data collection is ideal to reach out to these groups, but it is logistically difficult due to social distancing and travel restrictions during the MCO. In addition, our survey was not designed to be representative of the population. The policy implications of this research include creating regulations to protect $\mathrm{HCW}$ from being infected such as working in bubble systems, providing lodging for self-isolation, managing of HCW's number of household members, and regular risk-guided testing. 
Malaysian Journal of Public Health Medicine 2021, Vol. 21 (1): 90-95

Table 1: Baseline characteristics of respondents from Sabah and Sarawak.

\begin{tabular}{|c|c|c|c|}
\hline Variable & $\begin{array}{c}\text { Sabah } \\
N=158 \\
n(\%)\end{array}$ & $\begin{array}{c}\text { Sarawak } \\
\mathrm{N}=104 \\
\mathrm{n}(\%)\end{array}$ & P-value \\
\hline \multicolumn{4}{|c|}{ Work status } \\
\hline $\mathrm{HCW}$ & $58(36.7)$ & $47(45.2)$ & 0.269 \\
\hline Non-HCW & $70(44.3)$ & $41(39.4)$ & \\
\hline Missing & $30(19.0)$ & $16(15.4)$ & \\
\hline \multicolumn{4}{|l|}{ Education } \\
\hline Primary & $0(0)$ & $0(0)$ & 0.813 \\
\hline Secondary & $11(7.0)$ & 8 (7.7) & \\
\hline Tertiary & $147(93.0)$ & $96(92.3)$ & \\
\hline \multicolumn{4}{|l|}{ Gender } \\
\hline Female & $106(67.1)$ & 67 (64.4) & 0.816 \\
\hline Male & $50(31.7)$ & $35(33.7)$ & \\
\hline Other & $2(1.3)$ & $2(1.9)$ & \\
\hline \multicolumn{4}{|l|}{ Age (years) } \\
\hline $18-24$ & $8(5.1)$ & $15(14.4)$ & 0.003 \\
\hline $25-34$ & 57 (36.1) & $49(47.1)$ & \\
\hline $35-44$ & $46(29.1)$ & $18(17.3)$ & \\
\hline $45-54$ & $28(17.7)$ & $10(9.6)$ & \\
\hline $55-64$ & $16(10.1)$ & $8(7.7)$ & \\
\hline $65-74$ & $3(1.9)$ & $3(2.9)$ & \\
\hline $75-84$ & $0(0)$ & $1(1.0)$ & \\
\hline
\end{tabular}

Table 2: Comparison of the proportion of participants tested in Sabah and Sarawak.

\begin{tabular}{|c|c|c|c|c|c|c|c|c|c|c|}
\hline \multirow{2}{*}{ State } & \multicolumn{2}{|c|}{ Sabah } & \multicolumn{2}{|c|}{ Sarawak } & \multicolumn{2}{|c|}{ Combined } & \multicolumn{2}{|r|}{ HCW } & \multicolumn{2}{|c|}{ Non-HCW } \\
\hline & 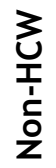 & 缶 & $\begin{array}{l}3 \\
\text { ํㅗ } \\
\dot{1} \\
\text { o }\end{array}$ & 总 & 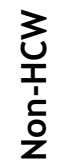 & 总 & $\begin{array}{l}\frac{1}{\sqrt{0}} \\
\stackrel{0}{\pi} \\
\sim\end{array}$ & 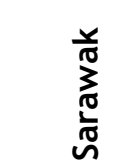 & $\begin{array}{l}\frac{1}{\sqrt{0}} \\
\stackrel{0}{0} \\
\sim\end{array}$ & 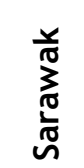 \\
\hline
\end{tabular}

\begin{tabular}{|c|c|c|c|c|c|c|c|c|c|c|}
\hline $\begin{array}{l}\text { Tested } \\
\mathrm{n}(\%)\end{array}$ & $\begin{array}{c}2 \\
(3.2)\end{array}$ & $\begin{array}{c}15 \\
(25.8)\end{array}$ & $\begin{array}{c}3 \\
(7.3)\end{array}$ & $\begin{array}{c}31 \\
(66.0)\end{array}$ & $\begin{array}{c}5 \\
(4.5)\end{array}$ & $\begin{array}{c}46 \\
(43.8)\end{array}$ & $\begin{array}{c}2 \\
(3.2)\end{array}$ & $\begin{array}{c}3 \\
(7.3)\end{array}$ & $\begin{array}{c}15 \\
(25.8)\end{array}$ & $\begin{array}{c}31 \\
(66.0)\end{array}$ \\
\hline $\begin{array}{l}\text { Not Tested } \\
\mathrm{n}(\%)\end{array}$ & $\begin{array}{c}68 \\
(97.1)\end{array}$ & $\begin{array}{c}43 \\
(74.1)\end{array}$ & $\begin{array}{c}38 \\
(92.7)\end{array}$ & $\begin{array}{c}16 \\
(34.0)\end{array}$ & $\begin{array}{c}106 \\
(95.5)\end{array}$ & $\begin{array}{c}59 \\
(56.2)\end{array}$ & $\begin{array}{c}68 \\
(97.1)\end{array}$ & $\begin{array}{c}38 \\
(92.7)\end{array}$ & $\begin{array}{c}43 \\
(74.1)\end{array}$ & $\begin{array}{c}16 \\
(34.0)\end{array}$ \\
\hline Total & $\begin{array}{c}70 \\
(100)\end{array}$ & $\begin{array}{c}58 \\
(100)\end{array}$ & $\begin{array}{c}41 \\
(100)\end{array}$ & $\begin{array}{c}47 \\
(100)\end{array}$ & $\begin{array}{l}111 \\
(100)\end{array}$ & $\begin{array}{c}105 \\
(100)\end{array}$ & $\begin{array}{c}70 \\
(100)\end{array}$ & $\begin{array}{c}41 \\
(100)\end{array}$ & $\begin{array}{c}58 \\
(100)\end{array}$ & $\begin{array}{c}47 \\
(100)\end{array}$ \\
\hline $\begin{array}{l}\text { Fisher's } \\
\text { exact } \\
p \text {-value }\end{array}$ & \multicolumn{2}{|c|}{$<0.001$} & \multicolumn{2}{|c|}{$<0.001$} & \multicolumn{2}{|c|}{$<0.001$} & \multicolumn{2}{|c|}{0.356} & \multicolumn{2}{|c|}{$<0.001$} \\
\hline
\end{tabular}


Table 3: Comparison of number of people in household and household composition status (living alone, with spouse or other) between non-HCW and HCW.

\begin{tabular}{|c|c|c|c|c|c|c|c|c|c|}
\hline \multirow{2}{*}{ State } & \multicolumn{3}{|c|}{ Sabah } & \multicolumn{3}{|c|}{ Sarawak } & \multicolumn{3}{|c|}{ Combined } \\
\hline & 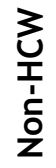 & 온 & $\frac{\stackrel{0}{2}}{\frac{2}{\sigma}}$ & 缶 & 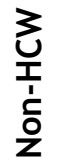 & 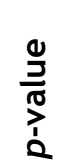 & 茎 & 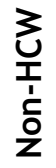 & $\frac{\stackrel{0}{2}}{\frac{0}{0}}$ \\
\hline
\end{tabular}

\begin{tabular}{|c|c|c|c|c|c|c|c|c|c|}
\hline $\begin{array}{l}\text { Alone } \\
\mathrm{n}(\%)\end{array}$ & $\begin{array}{c}3 \\
(4.3)\end{array}$ & $\begin{array}{c}7 \\
(12.1)\end{array}$ & \multirow[t]{3}{*}{$<0.001$} & $\begin{array}{c}3 \\
(7.3)\end{array}$ & $\begin{array}{c}3 \\
(6.4)\end{array}$ & \multirow[t]{3}{*}{1.000} & $\begin{array}{c}6 \\
(5.4)\end{array}$ & $\begin{array}{c}10 \\
(9.5)\end{array}$ & \multirow[t]{3}{*}{0.013} \\
\hline $\begin{array}{l}\text { Spouse only } \\
\mathrm{n}(\%)\end{array}$ & $\begin{array}{c}2 \\
(2.9)\end{array}$ & $\begin{array}{c}13 \\
(22.4)\end{array}$ & & $\begin{array}{c}4 \\
(9.8)\end{array}$ & $\begin{array}{c}4 \\
(8.5)\end{array}$ & & $\begin{array}{c}6 \\
(5.4)\end{array}$ & $\begin{array}{c}17 \\
(16.2)\end{array}$ & \\
\hline $\begin{array}{l}\text { Other groups } \\
\mathrm{n}(\%)\end{array}$ & $\begin{array}{c}65 \\
(92.9)\end{array}$ & $\begin{array}{c}38 \\
(65.5)\end{array}$ & & $\begin{array}{c}34 \\
(82.9)\end{array}$ & $\begin{array}{c}40 \\
(85.1)\end{array}$ & & $\begin{array}{c}99 \\
(89.2)\end{array}$ & $\begin{array}{c}78 \\
(74.3)\end{array}$ & \\
\hline
\end{tabular}

\begin{tabular}{|c|c|c|c|c|c|c|c|c|c|}
\hline $\begin{array}{l}\text { \#in } \mathrm{HH}=1 \\
\mathrm{n}(\%)\end{array}$ & $\begin{array}{c}3 \\
(4.3)\end{array}$ & $\begin{array}{c}6 \\
(10.3)\end{array}$ & \multirow[t]{7}{*}{$0.001^{*}$} & $\begin{array}{c}4 \\
(9.8)\end{array}$ & $\begin{array}{c}3 \\
(6.4)\end{array}$ & \multirow[t]{7}{*}{$0.746^{*}$} & $\begin{array}{c}7 \\
(6.3)\end{array}$ & $\begin{array}{c}9 \\
(8.6)\end{array}$ & \multirow[t]{7}{*}{$0.009^{*}$} \\
\hline $\begin{array}{l}\# \text { in } \mathrm{HH}=2 \\
\mathrm{n}(\%)\end{array}$ & $\begin{array}{c}5 \\
(7.1)\end{array}$ & $\begin{array}{c}18 \\
(31.0)\end{array}$ & & $\begin{array}{c}2 \\
(4.9)\end{array}$ & $\begin{array}{c}3 \\
(6.4)\end{array}$ & & $\begin{array}{c}7 \\
(6.3)\end{array}$ & $\begin{array}{c}21 \\
(20.0)\end{array}$ & \\
\hline $\begin{array}{l}\text { \#in } \mathrm{HH}=3 \\
\mathrm{n}(\%)\end{array}$ & $\begin{array}{c}13 \\
(18.6)\end{array}$ & $\begin{array}{c}7 \\
(12.1)\end{array}$ & & $\begin{array}{c}5 \\
(12.2)\end{array}$ & $\begin{array}{c}6 \\
(12.8)\end{array}$ & & $\begin{array}{c}18 \\
(16.2)\end{array}$ & $\begin{array}{c}13 \\
(12.4)\end{array}$ & \\
\hline $\begin{array}{l}\# \text { \#in } \mathrm{HH}=4 \\
\mathrm{n}(\%)\end{array}$ & $\begin{array}{c}10 \\
(14.3)\end{array}$ & $\begin{array}{c}8 \\
(13.8)\end{array}$ & & $\begin{array}{c}9 \\
(22.0)\end{array}$ & $\begin{array}{c}13 \\
(27.7)\end{array}$ & & $\begin{array}{c}19 \\
(17.1)\end{array}$ & $\begin{array}{c}21 \\
(20.0)\end{array}$ & \\
\hline $\begin{array}{l}\# \text { \#in } \mathrm{HH}=5 \\
\mathrm{n}(\%)\end{array}$ & $\begin{array}{c}12 \\
(17.1)\end{array}$ & $\begin{array}{c}8 \\
(13.8)\end{array}$ & & $\begin{array}{c}5 \\
(12.2)\end{array}$ & $\begin{array}{c}5 \\
(10.6)\end{array}$ & & $\begin{array}{c}17 \\
(15.3)\end{array}$ & $\begin{array}{c}13 \\
(12.4)\end{array}$ & \\
\hline $\begin{array}{l}\# \text { \#in } \mathrm{HH}=6 \\
\mathrm{n}(\%)\end{array}$ & $\begin{array}{c}9 \\
(12.9)\end{array}$ & $\begin{array}{c}4 \\
(6.9)\end{array}$ & & $\begin{array}{c}5 \\
(12.2)\end{array}$ & $\begin{array}{c}8 \\
(17.0)\end{array}$ & & $\begin{array}{c}14 \\
(12.6)\end{array}$ & $\begin{array}{c}12 \\
(11.4)\end{array}$ & \\
\hline $\begin{array}{l}\# \text { in } H H>=7 \\
\text { n (\%) }\end{array}$ & $\begin{array}{c}18 \\
(25.7)\end{array}$ & $\begin{array}{c}7 \\
(12.1)\end{array}$ & & $\begin{array}{c}11 \\
(26.8)\end{array}$ & $\begin{array}{c}9 \\
(19.2)\end{array}$ & & $\begin{array}{c}29 \\
(26.1)\end{array}$ & $\begin{array}{c}16 \\
(15.2)\end{array}$ & \\
\hline
\end{tabular}

All p-values are from Fisher's exact test, except ${ }^{*}$ which means Z-test for trend (\#in $\mathrm{HH}$, number in household)

\section{CONCLUSION}

In conclusion, the situational factors among HCW and non-HCW were higher testing rates and smallersized households among $\mathrm{HCW}$ when compared to non-HCW workers. Differences between HCW and non-HCW warrants further research in terms of their perceptions and attitudes towards this pandemic. Research may uncover different strategies applied by $\mathrm{HCW}$ in preventing infection, which if feasible, may be recommended for the public as well. Our early data that focuses on the comparison of HCWs and non HCWs would be able to guide the refinement of government policy and direct future infection prevention and control plans including strategies on widespread testing of the public. This is important as the government is gradually easing restrictions in Sabah and Sarawak, and nationwide.

\section{ACKNOWLEDGMENTS}

The authors would like to thank the Director General of Health Malaysia for permission to publish this paper and all the participants who volunteered in the study. Phaik Yeong Cheah and Tassawan Poomchaichote are members of the SoNAR-Global Network. They are grateful for the social science 
expertise and resources that are made available to them during the development of this project.

\section{Disclosures}

The study is supported by the Wellcome Trust through a Translation Partnership Award [210599] and a Wellcome Trust Strategic Award [096527]. The Mahidol Oxford Tropical Medicine Research Unit is funded by the Wellcome Trust [106698]. This study was also supported by the Sonar-Global project which has received funding from the European Union Horizon 2020 Research and Innovation Program [825671]. The funders had no role in study design, data collection and analysis, decision to publish, or preparation of the manuscript.

\section{REFERENCES}

1. Yang YS, Peng FJ, Wang RS, et al. The deadly coronaviruses: The 2003 SARS pandemic and the 2020 novel coronavirus epidemic in China. J Autoimmun $2020 \quad$ 109: 102434. https://doi.org/10.1016/j.jaut.2020.102434 (accessed 14 May 2020).

2. World Health Organization (WHO). Situation report $\quad-\quad 137 \quad 2020$. https://www.who.int/emergencies/diseases/n ovel-coronavirus-2019/situation-reports (accessed 6 June 2020).

3. Ministry of Health Malaysia. Situasi Terkini [Archives] 2020. http://covid19. moh.gov.my/terkini (accessed 21 May 2020).

4. Prime Minister's Office of Malaysia. The Prime Minister's Special Message on COVID-19 2020. https: / /www.pmo.gov.my/2020/03/perutusan -khas-yab-perdana-menteri-mengenai-covid19-16-mac-2020 (accessed 21 May 2020).

5. Laws of Malaysia. Act 155: Immigration Act 1959/63 2006. http://www.agc.gov.my/ (accessed 29 May 2020).

6. Sabah State Secretary. Temporary Prohibition (Additional) Order 2020.

7. Sarawak State Disaster Management Committee. Sarawak Disaster Information 2020. https://www.facebook.com/SarawakDisasterln fo/ (accessed 21 May 2020).

8. Saunders-Hastings PR, Krewski D. Reviewing the History of Pandemic Influenza: Understanding Patterns of Emergence and Transmission. Pathogens $2016 \quad 5$ : 66. https: //doi.org/10.3390/pathogens5040066 (accessed 14 May 2020).
9. Bernama. MCO: $96.8 \mathrm{pc}$ compliance rate in Sabah. Daily Express 2020. http: / /www. dailyexpress.com.my/news/15033 0/mco-96-8pc-compliance-rate-in-sabah/ (accessed 25 May 2020).

10. Petingi G. MCO compliance in Sarawak at 97.3 pct, says Sarawak Police Commissioner. The Borneo Post 2020. https: / / www.theborneopost.com/2020/05/01 /mco-compliance-in-sarawak-at-97-3-pct-sayssarawak-police-commissioner/ (accessed 19 May 2020).

11. Arumugam T, Khairulrjijal R. 325 medical workers test positive for Covid-19. New Straits Times 2020. https://www.nst.com.my/news/nation/2020/ 04/586972/325-medical-workers-test-positivecovid-19 (accessed 22 May 2020).

12. Kaos Jr J. No cases from Sarawak General Hospital cluster originated from Covid-19 wards, ICUs, says Health DG. The Star 2020. https: / /www.thestar.com.my/news/nation/20 20/04/30/no-cases-from-sarawak-generalhospital-cluster-originated-from-covid-19wards-icus-says-health-dg (accessed 5 June 2020).

13. Pan-ngum W, Poomchaichote T, Cuman G et al. Social, ethical and behavioural aspects of COVID-19 [version 1; peer review: 1 approved, 1 approved with reservations]. Wellcome Open Res $2020 \quad 5$ : 90. https: / /doi.org/10.12688/wellcomeopenres.15 813.1 (accessed 27 May 2020).

14. Tawie S. Seven Covid-19 positive cases from Sarawak General Hospital cluster detected after mass screening of clinical staff, says state health director. Malay Mail 2020. https://www.malaymail.com/news/malaysia/ 2020/05/06/seven-covid-19-positive-casesfrom-sarawak-general-hospital-clusterdetecte/1863685 (accessed 22 May 2020).

15. Van Beusekom M. Studies: $1 \%$ of healthcare workers had COVID-19. CIDRAP University of Minnesota 2020. https: / / www.cidrap.umn.edu/newsperspective/2020/05/studies-1-healthcareworkers-had-covid-19 (accessed 22 May 2020).

16. McCurry J, Ratcliffe R, Davidson H. Mass testing, alerts and big fines: the strategies used in Asia to slow coronavirus. The Guardian 2020. https: / /www.theguardian.com/world/2020/m $\mathrm{ar} / 11 /$ mass-testing-alerts-and-big-fines-the- 
strategies-used-in-asia-to-slow-coronavirus (accessed 22 May 2020).

17. Mohd Hanafiah K, Chang DW. Public knowledge, perception and communication behavior surrounding COVID-19 in Malaysia. Advance 2020.https://doi.org/10.31124/advance. 12102 816.v1 (accessed 21 May 2020). 